\title{
HUBUNGAN USIA DAN JARAK KEHAMILAN DENGAN KEJADIAN ABORTUS
}

\section{CORRELATIONS BETWEEN AGE AND DISTANCE OF PREGNANCY WITH ABORTUS INSIDENT}

\author{
Nuri Luthfiatil Fitri \\ Akper Dharma Wacana Metro
}

\begin{abstract}
ABSTRAK
Abortus sebagai salah satu penyebab kematian ibu merupakan masalah yang sangat membutuhkan perhatian. Menurut WHO diperkirakan sebesar 15\%-50\% kematian ibu terkait dengan abortus. Di Asia Tenggara angka kejadian abortus setiap tahunnya mencapai 4,2 juta dan di Indonesia mencapai 1,5 juta. Tujuan penelitian ini adalah diketahuinya hubungan usia dan jarak kehamilan dengan kejadian abortus di RSUD Jend. Ahmad Yani Metro tahun 2015. Jenis penelitian survey analitik menggunakan pendekatan case control. Populasi dalam penelitian ini adalah semua ibu hamil yang dirawat di RSUD Jend. Ahmad Yani Metro tahun 2014 yang berjumlah 518 orang dengan sampel yang diambil sebanyak 260 orang yang terdiri dari 130 orang pada kelompok kasus dan 130 orang untuk kelompok kontrol. Analisis dalam penelitian ini menggunakan uji bivariat chi square. Hasil uji statistik menunjukkan ada hubungan usia dengan kejadian abortus (p-value 0,000 OR 4,021; CI;95\%: 2,161-7,483), ada hubungan jarak kehamilan dengan kejadian abortus (p-value: 0,000, OR 3,955; CI;95\%: 2,354-8,556). Penelitian menunjukkan ada hubungan usia dan jarak kehamilan dengan kejadian abortus.
\end{abstract}

Kata Kunci : Usia, jarak kehamilan, kejadian abortus

\begin{abstract}
Abortion as one of the causes of maternal death is a matter of great concern. According to the WHO estimated at $15 \%$ $50 \%$ of maternal deaths associated with abortion. In Southeast Asia the annual incidence of abortion reaches 4.2 million and in Indonesia it reaches 1.5 million. The purpose of this study is to know the correlations between age and gestational distance with the incidence of abortion in hospitals Jend. Ahmad Yani Metro in 2015. The type of analytic survey research using case control approach. The population in this study were all pregnant women who were treated in RSUD Jend. Ahmad Yani Metro in 2014, amounting to 518 people with samples taken as many as 260 people consisting of 130 people in the case group and 130 people for the control group. The analysis in this study used chi square test. The results of statistical tests showed that there was an association of age with abortus occurrence (p-value 0,000 OR 4.021; CI; 95\%: 2,161-7,483), there was a correlation between pregnancy distance and abortus occurrence (pvalue: 0,000 , OR 3.955; CI; $95 \%: 2,354-8,556)$. Research shows there is a correlations between age and gestational distance with the incidence of abortion.
\end{abstract}

Keywords: Age, gestational distance, abortion 


\section{PENDAHULUAN}

Hasil analisis SDKI menunjukkan bahwa tren angka kematian maternal menunjukkan penurunan dari SDKI 1997 sampai dengan SDKI 2007. Rasio kematian maternal pada tahun 1997 adalah 390 kematian per 100.000 kelahiran hidup. Analisis yang tidak dipublikasi menunjukkan penurunan yang kecil menjadi 334 kematian per 100.000 kelahiran hidup pada periode 1993-1997. Rasio kematian maternal menurun menjadi 307 kematian per 100.000 kelahiran hidup pada SDKI 2002-2003 dan 228 kematian per 100.000 kelahiran hidup pada SDKI 2007. Namun, angka ini meningkat pada SDKI 2012 menjadi 359 kematian per 100.000 kelahiran hidup, sedangkan target yang ditetapkan dalam MDGs adalah 102 per 100.000 kelahiran hidup pada tahun 2015 dimana angka tersebut masih jauh dari target yang ditetapkan. Penyebab terbesar langsung kematian ibu di Indonesia sampai saat ini masih didominasi oleh perdarahan yaitu 42\%, Eklampsi/Preeklampsi 13\%, Abortus $11 \%$, Infeksi 10\%, Partus lama/persalinan macet $9 \%$ dan sebab lainnnya $15 \%{ }^{1}$.

Abortus sebagai salah satu penyebab kematian ibu merupakan masalah yang sangat membutuhkan perhatian. Menurut
WHO diperkirakan sebesar 15\%-50\% kematian ibu terkait dengan abortus. Komplikasi abortus berupa perdarahan atau infeksi dapat menyebabkan kematian. Itulah sebabnya mengapa kematian ibu yang disebabkan abortus sering tidak muncul dalam laporan kematian, tapi dilaporkan sebagai perdarahan atau sepsis. Diperkirakan 4,2 juta abortus terjadi setiap tahun di Asia Tenggara, dengan perincian 1,3 juta di Vietnam dan Singapura, antara 750.000 sampai 1,5 juta di Indonesia, 155.000 sampai 750.000 di Filipina dan 300.000 sampai 900.000 di Thailand ${ }^{2}$.

Berdasarkan data hasil pra survey yang dilakukan di RSUD Jend. Ahmad Yani Metro diketahui bahwa pada tahun 2013 angka kejadian abortus mencapai 69 kasus (16,58\%) dari 416 ibu hamil, tahun 2014 terdapat 137 kasus $(22,79 \%)$ dari 601 ibu hamil dan tahun 2015 tercatat sebanyak 155 kasus $(29,72 \%)$ dari 518 ibu hamil.

Abortus memiliki dampak yang cukup banyak bagi ibu. Komplikasi yang serius kebanyakan terjadi pada fase abortus yang tidak aman (unsafe abortion) walaupun kadangkadang dijumpai juga pada abortus spontan. Komplikasi terjadi akibat abortus meliputi perdarahan, uterus dalam posisi hiperretrofleksi, infeksi dan syok. Syok pada abortus bisa terjadi karena perdarahan (syok hemoragik) dan karena 
infeksi berat (syok endoseptik). Faktor yang dapat mempengaruhi terjadinya abortus cukup banyak meliputi infeksi, keracunan, penyakit kronis, gangguan fisiologis, trauma fisik, kelainan alat kandungan, gangguan kelenjar gondok, penyebab dari segi janin/plasenta, kematian janin akibat kelainan bawaan, kelainan kromosom, usia, paritas, jarak kehamilan terlalu dekat, dan lingkungan yang kurang sempurna. Selain itu, faktor prilaku juga dapat menyebabkan terjadinya abortus seperti merokok ${ }^{3}$.

Penelitian yang dilakukan Hamidah (2012) tentang faktor dominan yang berhubungan dengan kejadian abortus di RSUP Ciptomangunkusumo Jakarta menunjukkan bahwa pada hasil analisis multivariate variabel yang terbukti memiliki berhubungan yang paling dominan dengan kejadian abortus meliputi paritas (pvalue $=0,006 ; \quad \operatorname{Exp}(B)=6,911)$, Usia $(p-$ value $=0,000 ; \quad \operatorname{Exp}(B)=4,026), \quad$ riwayat abortus (p-value $=0,001 ; \operatorname{Exp}(B)=4,239)$ dan usia kehamilan $(\mathrm{p}$-value $=0,040 ; \operatorname{Exp}(B)=$ $0,513)^{4}$.

Berdasarkan uraian dan data prasurvei di atas serta belum adanya penelitian multifaktor yang berkaitan dengan abortus di RSUD Jend. Ahmad Yani Metro maka peneliti tertarik untuk melakukan penelitian tentang analisis faktor risiko yang berhubungan dengan kejadian abortus di RSUD Jend. Ahmad Yani Metro tahun 2015.

\section{METODE}

Jenis penelitian ini merupakan kuantitatif, Studi yang digunakan adalah studi analitik menggunakan pendekatan case control. Populasi dalam penelitian ini adalah seluruh ibu hamil yang dirawat di RSUD Jend. Ahmad Yani Metro tahun 2015 yang berjumlah 518 ibu hamil. besar sampel pada kelompok kasus sebanyak 130 orang, dengan perbandingan besar sampel antara kasus dan kontrol $=1: 1$ dimana pada kelompok kasus sebanyak 130 orang dan pada kelompok kontrol 130 orang maka total sampel yang digunakan adalah 260 orang. Pengumpulan data menggunakan lembar observasi. Analisa data menggunakan uji chi square. Penyajian data dalam bentuk tabel dan disertai narasi.

\section{HASIL}

Tabel 1.

Distribusi Frekuensi Responden Berdasarkan Tingkat Pendidikan di RSUD Jend. Ahmad Yani Metro

\begin{tabular}{|c|c|c|}
\hline Variabel & Jumlah & $\%$ \\
\hline \multicolumn{3}{|l|}{ Usia } \\
\hline Tinggi & 22 & 8,5 \\
\hline Menengah & 207 & 79,6 \\
\hline Dasar & 31 & 11,9 \\
\hline Jumlah & 260 & 100 \\
\hline
\end{tabular}




\section{Pekerjaan}

PNS

Wiraswasta

\section{2}

15

0,8

Tani

18

5,8

6,9

IRT/Tidak

bekerja

225

86,5

Jumlah 260

100

Berdasarkan tabel di atas, dapat

diketahui bahwa dari 260 responden sebagian besar memiliki pendidikan menengah $(79,6 \%)$ dan bekerja sebagai ibu rumah tangga $(86,5 \%)$.

Tabel 2.

Distribusi Frekuensi Usia dan Jarak Kehamilan Responden di RSUD Jend. Ahmad Yani Metro

\begin{tabular}{clcc}
\hline No & Variabel & $\boldsymbol{f}$ & $\boldsymbol{\%}$ \\
\hline $\mathbf{1}$ & Usia & & \\
& $<20 \&>35$ tahun & 66 & 25,4 \\
& $20-35$ tahun & 194 & 74,6 \\
\hline \multicolumn{2}{c}{ Jumlah } & 260 & 100,0 \\
\hline $\mathbf{2}$ & Jarak Kehamilan \\
& $<2$ tahun \\
& $\geq 2$ tahun & 56 & 21,5 \\
& $\quad$ Jumlah & 204 & 78,5 \\
\hline & & 100,0 \\
\hline
\end{tabular}

Berdasarkan tabel di atas dapat dijelaskan bahwa pada variabel usia dibagi dalam dua kelompok meliputi usia reproduksi kurang sehat untuk hamil dan bersalin yaitu pada usia $<20$ tahun $\&>35$ tahun dan usia reproduksi sehat yaitu pada usia antara 20-35 tahun. Berdasarkan data yang diambil dari 260 responden diketahui bahwa sebagian besar berada pada usia reproduksi sehat yaitu sebanyak 194 orang $(74,6 \%)$ sedangkan usia $<20$ tahun dan $>35$ tahun ditemukan sebanyak 66 orang $(25,4 \%)$. Dilihat dari jarak kehamilan yang dibagi dalam dua kelompok yaitu pada interval $<2$ tahun dan $\geq 2$ tahun, sebagian besar responden memiliki jarak kehamilan $\geq 2$ tahun yaitu sebanyak 204 orang $(78,5 \%)$, sedangkan yang memiliki jarak kehamilan $<2$ tahun ditemukan sebanyak 56 orang $(21,5 \%)$.

Tabel 3.

Hubungan Usia Kejadian Abortus di RSUD Jend. Ahmad Yani Metro

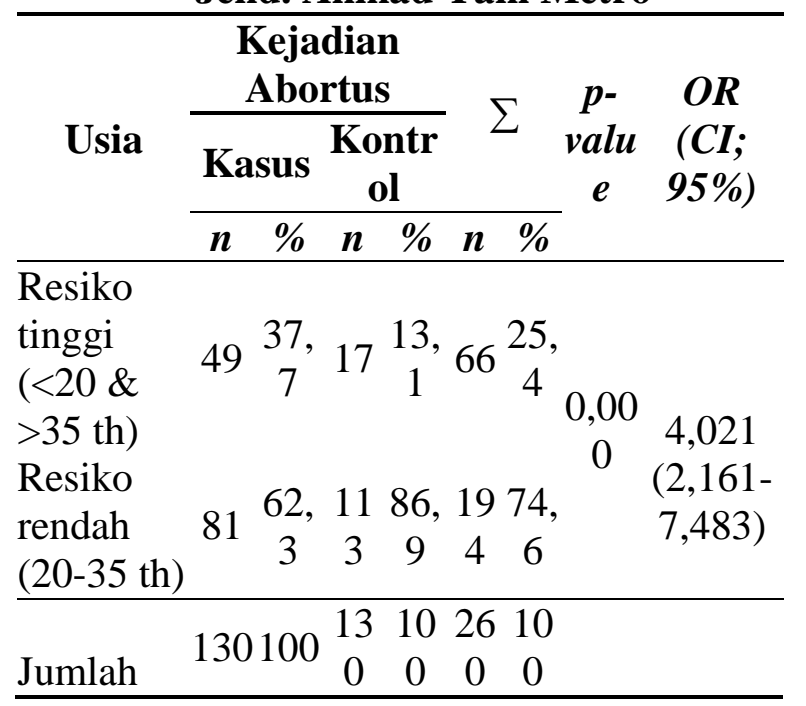

Berdasarkan tabel di atas menunjukkan bahwa dari 66 orang yang berada pada usia risiko tinggi ( $<20 \&>35$ tahun) sebagian besar ditemukan pada kelompok kasus yaitu sebanyak 49 orang $(37,7 \%)$ dan pada kelompok kontrol ditemukan sebanyak 17 orang (13,1\%). Sedangkan dari 194 orang yang berada pada usia risiko rendah (20-35 tahun) sebagian besar 
ditemukan pada kelompok kontrol yaitu sebanyak 113 orang $(86,9 \%)$ sedangkan pada kelompok kasus ditemukan sebanyak 81 orang $(62,3 \%)$. Pada hasil analisis diperoleh nilai signifikansi $p$-value $=0,000<\alpha 0,05$, maka secara statistik diyakini terdapat hubungan antara usia dengan kejadian abortus. Pada hasil analisis juga didapatkan nilai Odds Ratio (OR) sebesar 4,021 (CI;95\%: 2,161-7,483), dengan demikian maka ibu yang berusia $<20$ dan $>35$ tahun berisiko 4,021 kali lebih besar mengalami abortus dibandingkan dengan ibu yang berusia antara 20-35 tahun.

Tabel 4.

Hubungan Jarak Kehamilan dengan Kejadian Abortus di RSUD Jend. Ahmad Yani Metro

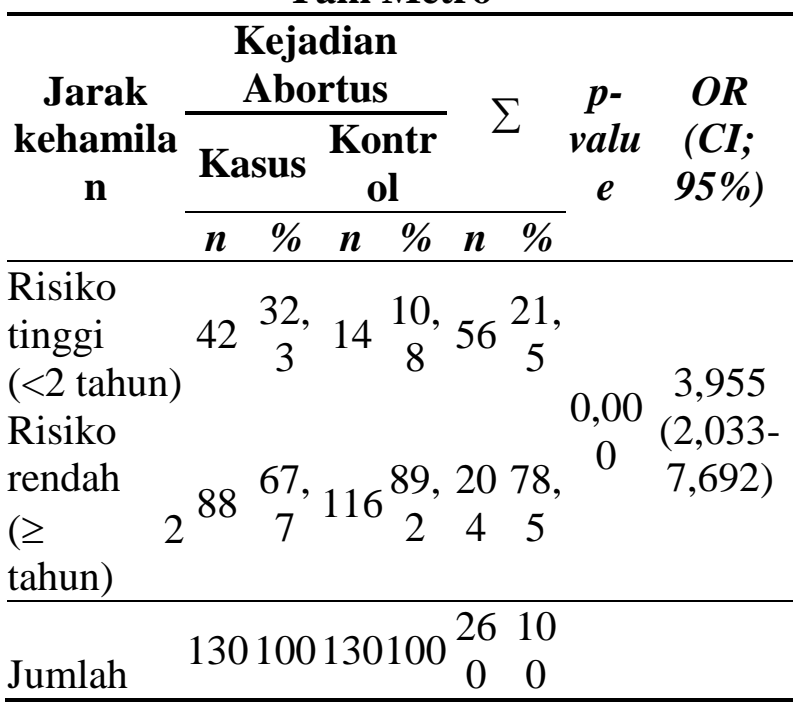

Berdasarkan tabel di atas dapat diketahui bahwa dari 56 responden yang memiliki jarak kehamilan risiko tinggi $(<2$ tahun) sebagian besar ditemukan pada kelompok kasus yaitu sebanyak 42 orang $(32,3 \%)$ dan pada kelompok kontrol ditemukan sebanyak 14 orang (10,8\%). Sedangkan dari 204 responden yang memiliki jarak kehamilan risiko rendah ( $\geq 2$ tahun) sebagian besar ditemukan pada kelompok kontrol yaitu sebanyak 116 orang $(89,2 \%)$, dan pada kelompok kasus ditemukan sebanyak 88 orang $(67,7 \%)$. Pada hasil analisis bivariat diperoleh nilai signifikansi $p$-value $=0,000<\alpha 0,05$, maka secara statistik diyakini terdapat hubungan antara jarak kehamilan dengan kejadian abortus. Pada hasil analisis juga didapatkan nilai Odds Ratio $(O R)$ sebesar 3,955 (CI;95\%: 2,354-8,556), dengan demikian maka ibu yang memiliki jarak kehamilan <2 tahun berisiko 3,955 kali lebih besar mengalami abortus dibandingkan dengan ibu yang memiliki jarak kehamilan $\geq 2$ tahun.

\section{PEMBAHASAN}

Usia adalah variabel yang selalu diperhatikan di dalam penyelidikanpenyelidikan epidemiologi. Angka-angka kesakitan maupun kematian di dalam hampir semua keadaan menunjukkan hubungan dengan usia $^{5}$. Kehamilan pada usia $<20$ tahun memiliki resiko, karena secara fisik kondisi rahim dan panggul belum berkembang secara optimal. Pertumbuhan dan perkembangan fisik ibu terhambat. Secara mental, ibu belum siap menghadapi perubahan yang terjadi saat 
kehamilan, belum siap menjalankan peran sebagai seorang ibu dan belum siap menghadapi masalah-masalah berumah tangga. Resiko yang terjadi pada usia kehamilan ini diantaranya abortus. Pada usia >35 tahun kondisi kesehatan ibu mulai menurun, fungsi rahim menurun, kualitas sel telur berkurang. Resiko yang mungkin terjadi pada kehamilan di usia ini adalah keguguran, preeklamsi, gangguan persalinan, perdarahan, BBLR dan cacat bawaan ${ }^{6}$.

Hasil penelitian menunjukkan bahwa dari 260 responden sebagian besar berada pada usia reproduksi sehat (20-35 tahun) yaitu sebanyak 194 orang $(74,6 \%)$ sedangkan usia $<20$ tahun dan $>35$ tahun ditemukan sebanyak 66 orang $(25,4 \%)$. Pada analisis bivariat menunjukkan bahwa faktor usia terbukti memiliki kontribusi terjadinya abortus dengan nilai signifikansi $\mathrm{p}$-value $=$ $0,000<\alpha 0,05$ dan nilai Odds Ratio (OR) sebesar 4,021 (CI;95\%: 2,161-7,483), dengan demikian maka ibu yang berusia <20 dan >35 tahun memiliki risiko 4,021 kali lebih besar mengalami abortus dibandingkan dengan ibu yang berada pada usia reproduksi sehat yaitu usia antara 20-35 tahun.

Hasil penelitian ini serupa dengan penelitian yang dilakukan oleh Rahmani (2014) tentang Faktor resiko kejadian abortus di RS Prikasih Jakarta Selatan menunjukkan bahwa paritas $(\mathrm{p}=0,001 \mathrm{OR}=2,287)$ dan riwayat abortus sebelumnya $(\mathrm{p}=0,009, \mathrm{OR}=$ 2,118) merupakan faktor risiko dan mempunyai hubungan bermakna dengan kejadian abortus. Sedangkan usia ibu $(\mathrm{p}=0,265)$ tidak mempunyai hubungan yang bermakna dengan kejadian abortus ${ }^{7}$.

Pada uraian di atas dapat dijelaskan bahwa usia ibu memiliki kontribusi terhadap terjadinya abortus dimana pada penelitian ini, ibu yang berada pada usia risiko tinggi $(<20 \&>35$ tahun) sebagian besar ditemukan pada kelompok kasus yaitu sebesar 37,7\% sedangkan pada kelompok kontrol ditemukan sebanyak $13,1 \%$. Hal ini dapat terjadi karena pada wanita usia muda ( $<20$ tahun) rahim dan panggul sering kali belum tumbuh mencapai ukuran dewasa. Akibatnya diragukan keselamatan dan kesehatan janin dalam kandungan. Sedangkan pada wanita yang hamil pada umur $>35$ tahun kondisi kesehatan ibu mulai menurun, fungsi rahim menurun, kualitas sel telur berkurang akibatnya jika kehamilan terjadi pada usia tersebut makan resiko terjadinya abortus akan semakin tinggi. Pada penelitian ini, variabel usia secara bersama-sama tidak memiliki hubungan yang signifikan dengan kejadian abortus. Hal ini dapat dipengaruhi oleh adanya faktor lain yang paling dominan mempengaruhi terjadinya abortus yaitu status gizi dan riwayat abortus. Namun demikian, dilihat dari hasil analisis 
bivariat maka usia tetap merupakan faktor risiko yang dapat meningkatkan kejadian abortus karena dengan meningkatnya usia ibu maka akan terjadi penurunan fungsi reproduksi dan semakin tinggi kelainan pada kromosom ovarium.

Jarak kehamilan adalah suatu pertimbangan untuk menentukan kehamilan yang pertama dengan kehamilan berikutnya. Pemerintah melalui Badan Koordinasi Keluarga Berencana Nasional (BKKBN) telah memberikan batasan jarak kelahiran/kehamilan minimal yaitu $\geq 2$ tahun dari kehamilan sebelumnya dengan jarak yang optimal dianjurkan adalah 36 bulan dan jarak kehamilan tidak dianjurkan adalah $<2$ tahun atau dianggap jarak kehamilan terlalu dekat karena pada jarak kehamilan $<2$ tahun kondisi rahim ibu belum pulih akibat dari kehamilan sebelumnya sehingga risiko terhadap terjadinya masalah kehamilan dan persalinan akan semakin meningkat ${ }^{6}$.

Hasil penelitian menunjukkan bahwa dari 260 responden sebagian besar memiliki jarak kehamilan $\geq 2$ tahun yaitu sebanyak 204 orang $(78,5 \%)$, sedangkan yang memiliki jarak kehamilan $<2$ tahun ditemukan sebanyak 56 orang $(21,5 \%)$. Pada analisis statistik bivariat menunjukkan bahwa seperti halnya variabel usia, pada variabel jarak kehamilan juga terbukti mempengaruhi kejadian abortus dengan nilai signifikansi pvalue $=0,000<\alpha 0,05$ dan nilai Odds Ratio $(\mathrm{OR})$ sebesar 3,955 (CI;95\%: 2,354-8,556) dengan demikian maka ibu yang memiliki jarak kehamilan $<2$ tahun berisiko 3,955 kali lebih besar mengalami abortus dibandingkan dengan ibu yang memiliki jarak kehamilan $\geq 2$ tahun.

Hasil penelitian ini sejalan dengan penelitian Kusniati (2007) tentang Hubungan Beberapa Faktor Ibu Dengan Kejadian Abortus Spontan (Studi Di Rumah Sakit Ibu Dan Anak An Ni'mah Kecamatan Wangon Kabupaten Banyumas Januari-Juni 2007) menunjukkan bahwa bahwa jarak kehamilan terbukti tidak berhubungan dengan kejadian abortus ( $p$ value $=1,000$ ). Berbeda dengan penelitian Pariani (2014) yang menunjukkan ada hubungan antara jarak kehamilan dengan kejadian abortus spontan, dimana jarak kehamilan terlalu dekat ( $<2$ tahun) memiliki peluang 2,709 kali terhadap kejadian abortus ${ }^{8}$

Berdasarkan uraian di atas dapat dijelaskan bahwa paritas terbukti memiliki kontribusi terhadap terjadinya abortus dimana ibu yang memiliki jarak kehamilan risiko tinggi ( $<2$ tahun) sebagian besar ditemukan pada kelompok kasus yaitu sebesar 32,3\% sedangkan pada kelompok kontrol ditemukan sebesar $10,8 \%$, hal ini dapat terjadi karena pada jarak kehamilan yang terlalu dekat ( $<2$ tahun) kondisi rahim masih belum pulih akibat persalinan 
sebelumnya dan belum bisa memaksimalkan pembentukan cadangan makanan bagi janin dan untuk ibu sendiri.

\section{DAFTAR PUSTAKA}

1. Depkes RI, 2014 Profil Kesehatan Indonesia. Indonesia : Departemen Kesehatan Indonesia

2. Azhari, 2012, Masalah abortus dan kesehatan Reproduksi perempuan. Bagian Obstetri \& Ginekologi FK UNSRI/ RSMH Palembang. http://digilib.unsri.ac.id

3. Nugroho, Taufan. 2010. Kasus Emergency Kebidanan; untuk kebidanan dan keperawatan. Yogyakarta: Nuha Medika.

4. Hamidah, 2012. Faktor Dominan Yang Berhubungan Dengan Kejadian Abortus Imminens.

http://ejurnal.poltekkesjakarta3.ac.id/ind ex.php/JITEK/article /view/23/17.

5. Notoatmodjo, 2010 Promosi Kesehatan Teori dan Aplikasi. Jakarta : Renika Cipta

6. BKKBN, 2007, 4 Terlalu Badan Kependudukan Keluarga Berencana Nasional http://nad.bkkbn.go.id

7. Rahmani, 2014. Faktor resiko kejadian abortus di RS Prikasih Jakarta Selatan, http://repository.uinjkt.ac.id/dspace/bitst ream/123456789/27175/1/SILMI\%20LIS ANI\%20RAHMANI-FKIK.pdf

8. Kusniati, 2007, Hubungan Beberapa Faktor Ibu Dengan Kejadian Abortus Spontan (Studi Di Rumah Sakit Ibu Dan Anak An Ni'mah Kecamatan Wangon 